\title{
Population dynamics of Rodents and Insectivores in lowland tropical rainforest ecosystem of Okomu National Park, Edo State, Nigeria
}

\author{
OMOGBEME, MI; OKE, CO
}

\author{
Department of Animal and Environmental Biology, University of Benin, P.M.B 1154, Benin City, Nigeria \\ Corresponding Author Email: moses.omogbeme@uniben.edu
}

\begin{abstract}
The community structure of rodents and insectivores in the lowland tropical rainforest of Okomu National Park, Edo State, Nigeria was assessed using a combination of live-trapping and sighting techniques during the dry and wet seasons. Seventeen species (14 species of rodent, 3 species of insectivores) were captured, and 3 species (all rodents) were recorded as observed species. Of the total 737 individuals trapped, 680 individuals (92.3\%) were rodents and 57 individuals (7.7\%) were insectivores, with 185 individuals recaptured. The abundance of rodents and insectivores was significantly higher during the dry season than the wet season $(\mathrm{p}<0.01)$. The Tullberg's softfurred mouse (Praomys tullbergi) was the most abundant species constituting $17.8 \%$ of the total number of captures, with the recapture of 38 individuals. The age composition of all captured small mammals varied significantly and between seasons. There was no significant difference in sex ratio for both seasons, however, males had higher capture frequency. This study suggests that seasonality tends to influence abundance and age structure of these small mammals, with no significant effect on their sex ratio. The rodent and insectivore species inhabiting the study area have a stable and thriving community, except for Atelerix albiventris.
\end{abstract}

DOI: https://dx.doi.org/10.4314/jasem.v22i3.5

Copyright: Copyright (C) 2018 Omogbeme and Oke. This is an open access article distributed under the Creative Commons Attribution License (CCL), which permits unrestricted use, distribution, and reproduction in any medium, provided the original work is properly cited

Dates: Received: 05 February 2018; Revised: 22 February: 2018; Accepted: 19 March 2018

Keywords: Okomu National Park, Rodents, Insectivores, Conservation

With deforestation intensifying, protected areas are gradually becoming final asylums for threatened species and natural ecosystem processes. However, many protected areas in the tropics are progressively becoming vulnerable to human encroachment, and as a result, declines in the abundance of species in many of Africa's protected areas is on the increase (Caro and Scholte, 2007; Laurance et al., 2012). The Okomu National Park comprises of relics of the primary rainforests with a complex assemblage of flora species (Agbelusi et al., 2003; Olaniyi et al., 2015), and it is the only lowland rainforest protected park in southern Nigeria. The indiscriminate logging and agricultural practices by neighbouring communities around its forest edges have resulted in the fragmentation of some parts of its habitats. Habitat fragmentation has been well documented to deplete critical resources such as shelter and food within rainforest ecosystems. The effects of depleting critical resources on population size and structure are particularly evident in small mammals, as it is common for their population densities to fluctuate extensively over time (Horskins, 2005).

Small mammals are the most numerous of all mammalian groups, with about $42 \%$ of all recorded mammalian species being rodents and insectivores (Wilson and Reeder, 2005). Rodents and insectivores are highly diverse groups. The order Rodentia is documented as the largest order of mammals with about 2277 species worldwide, while insectivore fauna is of 429 species with more than $70 \%$ being shrews (Kingdon, 1997). Rodents and insectivores are important components of many terrestrial ecosystems, as major consumers of primary productivity, as well as important prey for many vertebrate predators (Ofori et al., 2016). Alterations in the community structure of these small mammals can be used as alternative and a quick way of measuring environmental disturbance, due to their sensitivity to small changes in the environment (Avenant, 2011; Ofori et al., 2016). Some of these small mammals are also agricultural pests and carriers of zoonotic infections (Datiko and Bekele, 2014). General studies on the breeding biology of Nigerian small mammals especially rodents have been made, as well as studies relating to agricultural pest problems. However, the small mammals' species inhabiting many Nigerian forests especially protected areas are yet to be documented, and their community ecology yet to be extensively known.

Aspects of community structure (size, age structure, and sex ratio) are components of population studies which provide the essential information on the ecological status of species (Garshong and

Corresponding Author Email: moses.omogbeme@uniben.edu 
Attuquayefio, 2013). In this study, we surveyed the small mammal communities of the Okomu National Park to investigate seasonal changes in species abundance, structure and sex ratio. Thus, the objective of this study is to provide baseline data on the community structure of rodent and insectivore species in Okomu National Park, as well aid management decisions and future small mammal research in the study area.

\section{MATERIALS AND METHODS}

Description of Study Area: Okomu National Park is within the humid lowland rainforest zone of Nigeria, located in Edo State, south of Udo town and about $40 \mathrm{~km}$ west of Benin-City, and lies on between Latitudes $6^{\circ} 15^{\prime} \mathrm{N}$ and $6^{\circ} 25^{\prime} \mathrm{N}$; and Longitudes $5^{\circ} 09^{\prime} \mathrm{E}$ and $5^{\circ} 23^{\prime} \mathrm{E}$. It is the smallest of Nigeria's National Parks covering an area of $202.24 \mathrm{~km}^{2}$ and bordered to the east and west by Rivers Osse and Siluko respectively. The climate is tropical with two distinct seasons: the dry season (November to February) and wet seasons (March to October) (Soladoye and Oni, 2000). The soil in this area is acidic sandy loams, and the vegetation includes areas of swamp-forest, high forest, secondary forest and open shrublands (Okomu National Park, 2010). About eighty-four (84) plants species were reported within the park, with Entandrophragma angolense, Lovoa trichilioides, Anopyxis klaineana, Nauclea diderrichii termed vulnerable, and Diospyros crassiflora; endangered by the IUCN Red List data (Olaniyi et al., 2015).

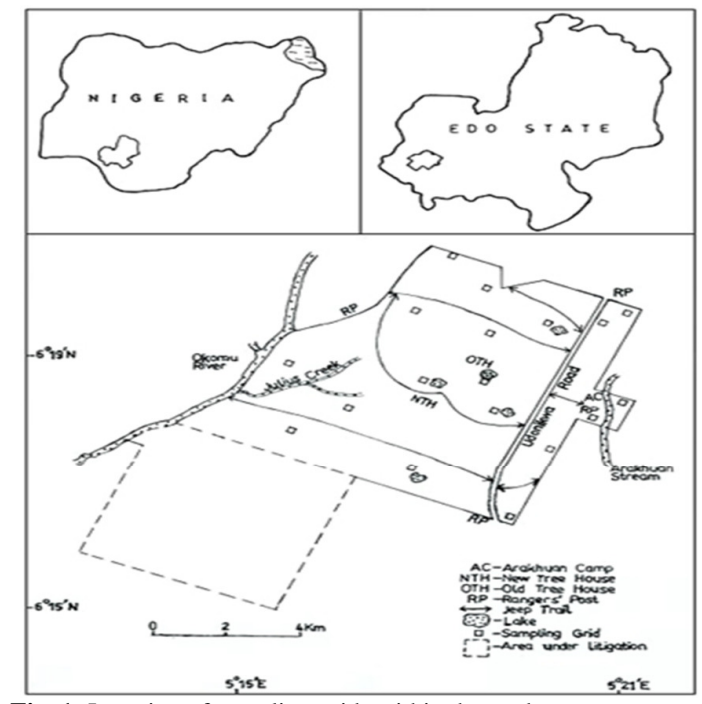

Fig. 1: Location of sampling grids within the study area
Sample Collection: Seven habitat types were identified based on topography, vegetation types, and land use. These include Arakhuan base camp (secondary forest), upland dense forest (open shrublands), lake shores (swamp forest), clearcut / fragmented regions (derived savannah), park fringes (boundaries), agricultural fields (farm bushes) and bottomland forest (secondary forest). Eighteen (18) sampling square grids $\left(70 \times 70 \mathrm{~m}^{2}\right)$ were selected to maximize the range of habitats surveyed and sampled during wet and dry seasons following the methods of Kasso et al. (2010) and Dakito and Bekele (2014). The indirect method (sighting) and direct method (live trapping) were adopted in the sampling of small mammals (Hoffman et al., 2010). Small mammals (rodents and shrews) were live-trapped using Capture-Mark-Recapture (CMR) technique as described by Datiko and Bekele (2014) and Fekdu et al. (2015); with a combination of Elliott traps and locally made metal box cages. Sampling was carried out in all eighteen (18) sampling square grids for two different seasons; dry season (November 2015 to February 2016) and rainy season (May 2016 to August 2016). A total of 49 standard Elliott traps (type A; $33 \times 10 \times 10 \mathrm{~cm}$ ) were set at $10 \mathrm{~m}$ interval per grid. In addition to the Elliott traps, metal box cages $(50 \times 25 \times 25 \mathrm{~cm})$ were also used to explore strategic places within $1 \mathrm{~m}$ of the trapping station. Trapping was conducted for four consecutive days in each square grid. The traps were baited with pieces of cassava tuber and occasionally palm fruits.

Sample Analysis: Captured animals were transferred into mesh cage, examined for reproductive condition (abdominal or scrotal testes in males and enlarged nipples in females), and identified. All recorded animals were identified to species level using Happold (1987) and Kingdon (2004). The animals were weighed (in grams) using PESOLA medio-line spring scale. Individuals were marked by toe-clipping before released at the point of capture. Small mammal field handling techniques were followed as described by Davies and Howell (2004). Age structure of small mammals' species was determined by categorizing them into three broad age-classes: juvenile, sub-adult, and adult, using their respective weight limits as body weight in animals are known to be directly correlated with age (Pucek and Lowe, 2009).

Data Analysis: Pearson's $\chi^{2}$ test was used to compare relative abundance, age structure and sex distribution of species between seasons. All statistical analyses 
were performed using SPSS statistical program version 22.0 (IBM Corporation).

\section{RESULTS AND DISCUSSIONS}

Total Abundance and Temporal Variation: Species abundance of all captured small mammals species is represented in Table 1. A total of 737 individuals belonging to 21 species were recorded from 18 sampled grids in 7 different ecological habitats both dry and wet seasons. Out of the 737 small mammals trapped, $680(92.3 \%)$ individuals were rodents and 57 (7.7\%) individuals were insectivores. Numerical abundance is dominated by family Muridae with 544 (74\%) individuals, followed by Soricidae with 53 $(7.2 \%)$ individuals and the least being Erinaceidae with $4(0.5 \%)$ individuals. The 443 individuals captured during the dry season was significantly higher than the 294 individuals recorded in the wet season $\left(\chi^{2}=30.12\right.$, df $\left.=1, \mathrm{p}(0.00)<0.01\right)$. The Tullberg's soft-furred mouse (P. tullbergi) was the most abundant species in all sampled habitat types constituting $17.8 \%$ of the total capture and $A$. albiventris being the least abundant species $(0.5 \%)$. Of the 185 individuals recaptured, $P$. tullbergi was recaptured most often having $38(20.5 \%)$ recapture, the African brush-tailed porcupine (A. africanus) had the least recapture (4), while $T$. gregorianus and $A$. albiventris both had zero (0) recapture. All small mammals species were recorded both in the dry and wet seasons, except for $A$. albiventris that was not recorded in the wet season. The difference in total capture between seasons was statistically significant for only three species; P. tullbergi $\left(\chi^{2}=9.35\right.$, df $=1$, $\mathrm{p}(0.00)<0.01), R$. rattus $\left(\chi^{2}=8.23\right.$, df $=1, \mathrm{p}(0.00)<$ $0.01)$ and A. niloticus $\left(\chi^{2}=6.74\right.$, df $=1, \mathrm{p}(0.00)<$ 0.01 ). Small mammals' abundance varied between sampled habitats types and between seasons in each sampled habitat type. The mean number of individuals per sampled habitat type ranged from $19.13 \pm 8.18$ in the Park fringes (boundaries) to 107.50 \pm 30.41 in the Agricultural field (farm bushes). Small mammals were also significantly more abundant during the dry season than in the wet season in five sampled habitat types (Arakhuan camp (secondary forest); $\chi^{2}=8.26$, df $=1, \mathrm{p}(0.00)<0.01$, Lake shores (swamp forest); $\chi^{2}=8.50$, df $=1, \mathrm{p}(0.00)<0.01$, Clear-cut / fragmented region (derived savannah); $\chi^{2}=$ $6.39 \mathrm{df}=1, \mathrm{p}(0.01)<0.05$, Park fringes (boundaries); $\chi^{2}=8.02$, df $=1, \mathrm{p}(0.00)<0.01$, and Agricultural fields (farm bushes); $\chi^{2}=6.37$, df $=1, p(0.01)<0.05$ ). There was no significant difference in total abundance between seasons in the Upland dense forest (open shrub lands) and Bottomland forest (secondary forest) $(\mathrm{p}>0.05)$. The total of 737 individuals (680 rodents and 57 insectivores) recorded in both dry and wet seasons in Okomu National Park was higher than 392 individuals (218 rodents and 174 insectivores) recorded in in Ogba Forest Reserve (Iyawe, 1989), 20 individuals (14 rodents and 6 shrews) recorded in Cross River National Park (Anadu, 2007), and 36 individuals (35 rodents and 1 pangolin) recorded in Idu, Akwa Ibom State (Akpan et al., 2015). This may have occurred due to a wider expanse of forest with larger sample size. The relative higher number of captured small mammals in the study area during the dry season as compared to the wet season may have been due to the incessant rainfall between the month of June and July. Most of the small mammals were observed to have a restricted movement for the most part of June and July especially the diurnal species. The dominance of the family Muridae (contributing 74\% of all captured small mammals), with $P$. tullbergi, $R$. rattus, and $M$. natalensis being the most abundant species show typical Afrotropical small mammals' abundance pattern and has been well documented (Anadu, 2007; Kasso et al., 2010; Datiko and Bekele, 2014; Fekdu et al., 2015). The high abundance of $P$. tullbergi in the study area is similar to the previous report on small mammals in Nigerian forests and in West African forests regions. This may be attributed to their breeding activity, with the species recorded to be sexually active throughout the year peaking during the dry season (Happold, 1977; Ofori et al., 2013)

Age Structure and Temporal Variation: Of all captured small mammals, the adults were the most numerous with juveniles being the least (Table 2). Adults comprised 549 (74.5\%), sub-adults 117 $(15.9 \%)$ and juveniles 71 individuals $(9.6 \%)$, with the difference in the abundance of age group highly significant $\left(\chi^{2}=566.11\right.$, df $\left.=2, p(0.00)<0.01\right)$. The composition of age groups and relative abundance of captured small mammals between dry season and wet season is represented in Table 3. The relative abundance of small mammals in the dry and wet seasons was $60.11 \%$ and $39.89 \%$, respectively. The total capture for adult group was significantly higher during the dry season $\left(\chi^{2}=29.37\right.$, df $=1$, p $(0.00)<$ $0.01)$. Total capture for the sub-adult group was also significantly higher during the dry $\left(\chi^{2}=17.30, \mathrm{df}=1\right.$, $\mathrm{p}(0.00)<0.01)$. Unlike the adult and sub-adult groups, a higher number of juveniles was recorded in the wet season. Of the 71 juveniles captured during both seasons, 24 juveniles were captured during the dry season accounting for $5.41 \%$ of the total capture 
in the dry season and 47 juveniles during the wet season accounting for $15.9 \%$ of the total capture in the wet season. This variation in number of juveniles between seasons was also highly significant $\left(\chi^{2}=\right.$ $7.45, \mathrm{df}=1, \mathrm{p}(0.00)<0.01)$.

\begin{tabular}{|c|c|c|c|c|c|}
\hline Species & $\begin{array}{c}\text { Dry } \\
\text { Season }\end{array}$ & $\begin{array}{c}\text { Wet } \\
\text { Season }\end{array}$ & $\begin{array}{c}\text { Total Capture } \\
\text { (Recapture) }\end{array}$ & $\begin{array}{c}\text { Relative } \\
\text { Abundance }(\%)\end{array}$ & $\begin{array}{l}\text { IUCN Red List } \\
\text { category }\end{array}$ \\
\hline Praomys tullbergi & 83 & 48 & $131(38)$ & 17.8 & L.C \\
\hline Rattus rattus & 47 & 23 & $70(23)$ & 9.5 & L.C \\
\hline Mastomys natalensis & 38 & 26 & $64(15)$ & 8.7 & L.C \\
\hline Mus musculoides & 29 & 23 & $52(12)$ & 7.1 & L.C \\
\hline Cricetomys gambianus & 27 & 22 & 49 (14) & 6.6 & L.C \\
\hline Xerus erythropus & 30 & 17 & $47(11)$ & 6.4 & L.C \\
\hline Lophuromys sikapusi & 25 & 19 & $44(9)$ & 6 & L.C \\
\hline Lemniscomys striatus & 26 & 17 & $43(12)$ & 5.8 & L.C \\
\hline Dasymys rufulus & 18 & 24 & $42(8)$ & 5.7 & L.C \\
\hline Arvicanthis niloticus & 27 & 11 & $38(13)$ & 5.2 & L.C \\
\hline Hylomyscus alleni & 19 & 14 & $33(7)$ & 4.5 & L.C \\
\hline Crocidura crossei & 17 & 12 & $29(5)$ & 3.9 & L.C \\
\hline Gerbilliscus robustus & 17 & 10 & $27(8)$ & 3.7 & L.C \\
\hline Crocidura flavescens & 14 & 10 & $24(6)$ & 3.2 & L.C \\
\hline Thryonomys gregorianus & 15 & 8 & $23(0)$ & 3.1 & L.C \\
\hline Atherurus africanus & 7 & 10 & $17(4)$ & 2.3 & L.C \\
\hline Atelerix albiventris & 4 & - & $4(0)$ & 0.5 & L.C \\
\hline Heliosciurus rufobrachium* & $*$ & $*$ & & & L.C \\
\hline Hystrix cristata* & $*$ & $*$ & & & L.C \\
\hline Phataginus tricuspis* & $*$ & $*$ & & & L.C \\
\hline Protoxerus stangeri ${ }^{*}$ & $*$ & $*$ & & & L.C \\
\hline Total Capture & 443 & 294 & $737(185)$ & & \\
\hline
\end{tabular}

*Observed Species, - Absence, L.C - Least Concern

Table 2: Body weights limits (in grams) of captured species (total capture in parenthesis)

\begin{tabular}{llll}
\hline & \multicolumn{3}{c}{ Weight $($ g) } \\
\cline { 2 - 4 } Species & Adults & Sub-adults & Juveniles \\
\hline Praomys tullbergi & $>30(86)$ & $20-30(26)$ & $<20(19)$ \\
Rattus rattus & $>100(51)$ & $50-100(11)$ & $<50(8)$ \\
Mastomys natalensis & $>50(55)$ & $30-50(4)$ & $<30(5)$ \\
Mus musculoides & $>20(42)$ & $10-20(8)$ & $<10(2)$ \\
Cricetomys gambianus & $>900(35)$ & $400-900(4)$ & $<400(10)$ \\
Xerus erythropus & $>400(38)$ & $200-400(3)$ & $<200(6)$ \\
Lophuromys sikapusi & $>40(41)$ & $30-40(2)$ & $<30(1)$ \\
Lemniscomys striatus & $>40(33)$ & $30-40(6)$ & $<30(4)$ \\
Dasymys rufulus & $>70(36)$ & $50-70(2)$ & $<50(4)$ \\
Arvicanthis niloticus & $>100(17)$ & $50-100(21)$ & $<50(0)$ \\
Hylomyscus alleni & $>20(27)$ & $10-20(6)$ & $<10(0)$ \\
Crocidura crossei & $>10(22)$ & $5-10(7)$ & $<5(0)$ \\
Gerbilliscus robustus & $>50(19)$ & $30-50(3)$ & $<30(5)$ \\
Crocidura flavescens & $>30(20)$ & $20-30(4)$ & $<20(0)$ \\
Thryonomys gregorianus & $>400(12)$ & $200-400(6)$ & $<200(5)$ \\
Atherurus africanus & $>900(13)$ & $400-900(3)$ & $<400(1)$ \\
Atelerix albiventris & $>400(2)$ & $200-400(1)$ & $<200(1)$ \\
\hline
\end{tabular}

Table 3: Composition of age groups of captured small mammals between seasons

\begin{tabular}{lccccc}
\hline & \multicolumn{3}{c}{ Age groups } & & Total \\
\cline { 2 - 5 } Seasons & Adult & Subadult & Juveniles & & $\begin{array}{c}\text { catch } \\
\text { Relative } \\
\text { Abundance }\end{array}$ \\
\hline Dry (Nov, 2015-Feb, 2016) & 338 & 81 & 24 & 443 & $60.11 \%$ \\
Wet (May-Aug 2016) & 211 & 36 & 47 & 294 & $39.89 \%$ \\
Total & 549 & 117 & 71 & 737 & $\chi^{2}=30.12, \mathrm{P}<0.01$ \\
\hline
\end{tabular}

The composition of age groups and their relative abundance in the population of small mammals in Okomu is observed to be influenced by seasonality.
Adult and sub-adult groups had higher population size during the dry season than the wet season while juveniles had higher population size during the wet

Omogbeme, $\mathrm{MI}$; Oke, $\mathrm{CO}$ 
season. This might be due to the correlation between rainfall and the breeding patterns of for the majority of tropical small mammals (Happold, 1979; Datiko and Bekele, 2013), with most of the small mammals' species taking advantage of the availability of food and dense vegetation cover during the wet season to produce many offspring.

Sex Distribution and Temporal Variation: Of the total captured individuals in all trapping occasions, males were captured more often, comprising 388 $(52.6 \%)$ individuals and females 349 (47.4\%) individuals, the variation in number between sex was however not significant $\left(\chi^{2}=2.06\right.$, df $=1, \mathrm{p}(0.15)>$ $0.05)$. Sex ratio was male-biased $(ð 1.2:+1)$ in the dry season and unity $(\hat{\jmath} 1: q 1)$ in the wet season (Fig. 2).

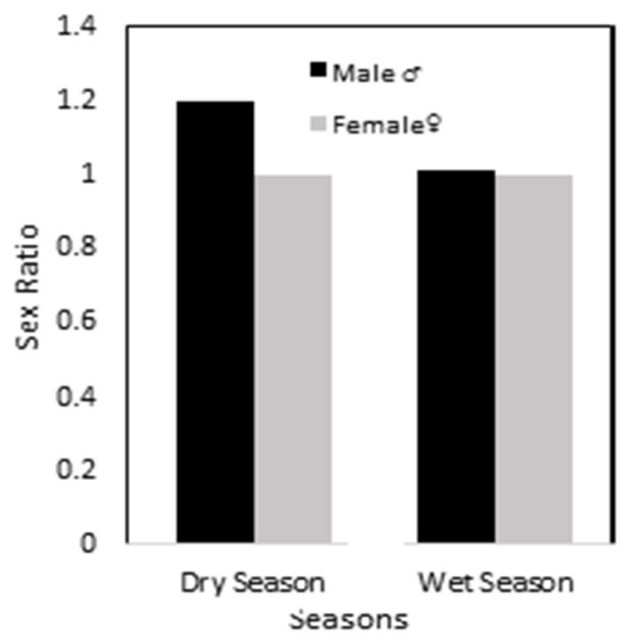

Fig. 2: Sex ratio and temporal variation of captured small mammals

The sex distribution of most species revealed that as the number of population increases the abundance of males also increases. Higher capture frequency of males might be due to the fact that males are more active than females, their ability to travel over greater distances and as well consume novel bait may have led to a higher probability of being trapped. Therefore, differences in movement behaviour rather than an unequal reproductive effort by parents lead to a male-biased sex ratio (Bantihun and Bekele, 2015).

Conclusion: This study suggests that the rodent and insectivore species inhabiting the Okomu National Park have a stable and thriving community, except for $A$. albiventris. Seasonality tends to influence the activities of the majority of these species as indicated by their abundance and age structure between seasons, with no significant effect on sex ratio. The higher abundance of juvenile age during the wet season as compared to the dry season confirms the correlation between rainfall and the breeding patterns for the majority of tropical small mammals' species.

Acknowledgements: This study was undertaken with the support of the Department of Animal and Environmental Biology, University of Benin and the Nigerian National Park Service, Okomu Chapter. The authors wish to thank all field guide in the Okomu National Park for their support.

\section{REFERENCES}

Agbelusi, EA; Ogunjemite, BG; Koyenikan, IO; Okeyoyin, O A (2003). The primate fauna and the distribution of chimpanzees of Okomu National Park, Edo State, Nigeria. J. Trop. For Res. Manage. 19: 161-170.

Akpan, A; Esenowo, I; Egwali, E; James, S (2015). The checklist and abundances of Small Mammals in Idu, Akwa Ibom State, Nigeria. $J$. Appl. Sci. Environ. Manage. 19 (1) 71 - 75

Anadu, P (2007). A Preliminary Survey of Small Mammals in the Oban Division, Cross River National Park. NCF-WCS Biodiversity Research Programme. 9pp

Avenant, N (2011). The potential utility of rodents and other small mammals of indicators of ecosystem integrity of South African grasslands. S. Afr. J. Wildlife Res. 38: 626-639.

Bantihun, G; Bekele, A (2015). Diversity and habitat association of small mammals in Aridtsy forest, Awi Zone, Ethiopia. Zoo Res. 36(2):88-94.

Caro, T; Scholte, P (2007). When protection falters. Afr. J. Eco. 45: 233 - 235.

Craigie, ID; Baillie, JE; Balmford, A; Carbone, C; Collen, B; Green, RE; Hutton, JM (2010). Large mammal population declines in Africa's protected areas. B. Cons. 143: 2221-2228

Datiko, D; Bekele, A (2013). Species composition and abundance of small mammals in Chebera- 
Churchura National Park, Ethiopia. J. Eco Nat. Env. 5(6):95-102.

Datiko, D; Bekele, A (2014). Habitat association and distribution of rodents and insectivores in Chebera Churchura National Park, Ethiopia. Trop. Eco 55(2): 221-229

Davies, G; Howell, K (2004). Small Mammals: Bats, Rodents and Insectivores. In: African Forest Biodiversity, Earthwatch Institute, United Kingdom.

Fekdu, A; Bekele, A; Datiko, D (2015). Comparative study of species composition, relative abundance and distribution of rodents between exclosure and control sites in the Web Valley of the Bale Mountains National Park, Ethiopia. P. Univ. J. Zoo 30(2): 57-64.

Garshong, R; Attuquayefio, D (2013). Aspects of the Ecology of Rodents in the Owabi Wildlife Sanctuary, Ghana: Sex-ratio, Age Structure and Reproductive Characteristics. Asian J. Appl. Sc. 1(4): 134-140.

Happold, DCD (1979). Age structure of a population of Praomys tullbergi (Muridae, Rodentia) in Nigerian Rainforests. Rev. Eco. (Terre Vie) 33: 253-274

Happold, DCD. (1987). Checklist of Nigerian Mammals (Table) In Happold DCD. The Mammals of Nigeria. Oxford: Oxford University Press

Hoffmann, A; Jan, D; Francesco, R; Juliane, S; Christian V; Gudrun W (2010). Field Methods and Techniques for Monitoring Mammals. J. Mammals. 19:484-527

Horskins, K (2005). The effectiveness of wildlife corridors in facilitating connectivity: assessment of a model system from the Australian Wet Tropics. Ph.D. Queensland University of Technology. Brisbane.

IBM Corporation; SPSS statistical program Version 22.0 (SPSS Inc., Chicago, Illinois, USA)

IUCN (2017). The International Union for Conservation of Nature (IUCN) Red List of Threatened Species.

Iyawe, JG (1989). The ecology of small mammal in Ogba Forest Reserve, Nigeria. J. Trop. Eco. 5: 51-64

Omogbeme, $\mathrm{MI}$; Oke, $\mathrm{CO}$
Kasso, M; Bekele, A; Hemson, G (2010). Species composition, abundance and habitat association of rodents and insectivores from Chilalo-Galama Mountain range, Arsi, Ethiopia. Afr. J. Eco.48: 1105-1114

Kingdon, J (1997). The Kingdon field guide to African mammals. Academic Press, San Diego, California.

Kingdon, J. (2004). The Kingdon Pocket Guide to African Mammals. Princeton University Press, Princeton.

Laurance, WF; Useche, DC; Rendeiro, J; Kalka, M; Sloan, S; Laurance, SG; Campbell, M (2012). Averting biodiversity collapse in tropical forest protected areas. Nat. 489: 290-294

Ofori, BY; Attuquayefio, DK; Owusu, EH (2013). Aspects of the ecology of the tullberg's softfurred mouse (Praomys tullbergi: Thomas 1894) in mount Afadjato, Ghana. J. Exper. Bio. Agri. Sci. 1(5): 398-404

Ofori, BY; Attuquayefio, DK; Owusu, EH; Musah, Y; Ntiamoa-Baidu, Y (2016). Spatio-temporal variation in small mammal species richness, relative abundance and body mass reveal changes in a coastal wetland ecosystem in Ghana. Envir. Monit. Assess. 188(6): 1-10.

Okomu National Park (2010). Nigeria National Park Service Annual reports

Olaniyi, O; Ogunjemite, B; Akindele, S (2015). Ecotourism development in Okomu National Park, Nigeria. J. Sust. Dev. Afr. 17 (7): 51-74.

Pucek, Z; Lowe, V (2009). Age Criteria in Small Mammals, In: Small Mammals: Their Productivity and Population Dynamics (F.B. Golley, K. Petrusewicz and L. Ryszkowski, Eds.) Cambridge University Press, Cambridge, United Kingdom. pp 55-72

Soladoye, M; Oni, O (2000). Biodiversity studies at Okomu Forest Reserve in Edo State. A report of the National Agricultural Research Project.

Wilson, DE; Reeder, DM (2005). Mammal species of the world: A Taxonomic and Geographic Reference. 3rd edn Vol. I. Maryland: Johns Hopkins University Press 